\title{
Antioxidant enzymes and proteins of wetland plants: Their relation to $\mathrm{Pb}$ tolerance and accumulation
}

\author{
Junxing Yang • Zhihong Ye
}

Received: 4 December 2013 / Accepted: 16 September 2014 / Published online: 2 October 2014

(C) Springer-Verlag Berlin Heidelberg 2014

\begin{abstract}
Constructed wetlands used to clean up toxic metals such as lead $(\mathrm{Pb})$ from contaminated wastewater are considered as an effective and low-cost technology. The effect of $\mathrm{Pb}$ on the biomass, tolerance, soluble protein, and antioxidant enzymes in 18 candidate wetland plant species grown in soils without (control) and spiked with 900 and $1800 \mathrm{mg} \mathrm{Pb} \mathrm{kg}^{-1}$ was studied in a pot trial. Our pot experiment showed that the biomass, tolerance, and leaf protein contents decreased with increasing concentrations of $\mathrm{Pb}$ in soil. There were significant differences between the plants in their $\mathrm{Pb}$ tolerance indices (29-82\% in the $900 \mathrm{mg} \mathrm{Pb} \mathrm{kg}^{-1}$ amended soil) and also $\mathrm{Pb}$ uptake (13-749 $\mathrm{mg} \mathrm{kg}^{-1}$ in shoots and $1112-4891 \mathrm{mg} \mathrm{kg}^{-1}$ in roots, in the same treatments). Activities of superoxide dismutase (SOD) and peroxidase (POD) in leaves of most of the plants increased with increasing level of soil $\mathrm{Pb}$ concentration. Conversely, catalase (CAT) activity in leaves declined when plants were subjected to $\mathrm{Pb}$ stress. Lead accumulation by the 18 wetland plant species screened was strongly dependent on the species and $\mathrm{Pb}$ concentrations in the soil. However, $\mathrm{Pb}$ translocation from root to shoot was generally low in all species. Increases in SOD and POD activities suggest that the antioxidant system may play an important role in alleviating $\mathrm{Pb}$ toxicity in wetland plants. The data obtained should
\end{abstract}

Responsible editor: Philippe Garrigues

J. Yang $\cdot$ Z. Ye $(\bowtie)$

Key Laboratory of Biodiversity Dynamics and Conservation of Guangdong Higher Education Institutes, College of Ecology and Evolution, School of Life Sciences, Sun Yat-sen University, Guangzhou 510006, People's Republic of China

e-mail: 1ssyzhh@mail.sysu.edu.cn

J. Yang

Center for Environmental Remediation, Institute of Geographic Sciences and Natural Resources Research, Chinese Academy of Sciences, Beijing 100101, People's Republic of China help in future species selection for the use in designing wetlands in $\mathrm{Pb}$-contaminated environments.

Keywords Accumulation · Antioxidant enzyme $\cdot$ Lead $(\mathrm{Pb})$. Tolerance index · Toxicity $\cdot$ Wetland plant

\section{Introduction}

Wastewater contaminated by heavy metals (e.g., $\mathrm{Pb}$ ) is a serious environmental problem as a result of the mining industry in many countries (Singh et al. 2004; Sharma et al. 2007). In China, large areas of land (including paddy fields) in mining areas have been contaminated by $\mathrm{Pb}$ due to irrigation with $\mathrm{Pb}$-contaminated wastewater arising from mineral processing plants (Li et al. 2009; Liu et al. 2013). High $\mathrm{Pb}$ concentrations in paddy soils $\left(386 \mathrm{mg} \mathrm{kg}^{-1}\right.$ at the Dabaoshan and $2780 \mathrm{mg} \mathrm{kg}^{-1}$ at Fankou mining areas) have been reported in South China (Zhuang et al. 2009; Li et al. 2012). There is an urgent need to develop cost-effective methods to control and remediate contaminated wastewaters in order to ensure safe crop production practices in areas such as these affected by $\mathrm{Pb}$ contamination.

Constructed wetlands have, for some time, been considered as an effective, low-cost, and practical approach for the clean up of metal-contaminated wastewaters (Sheoran and Sheoran 2006; Vymazal 2011). In a constructed wetland system, the plant is a key component in metal removal via filtration, adsorption, and cation exchange, and through plant-induced chemical changes in the rhizosphere (Wright and Otte 1999). Cattail (Typha latifolia L.) and common reed (Phragmites australis (Cav.) Trin. ex Steud.) have been used successfully for the phytoremediation of $\mathrm{Pb} / \mathrm{Zn}$ mine tailings under waterlogged conditions (Ye et al. 2004).

The uptake and accumulation of $\mathrm{Pb}$ by wetland plants are strongly governed by substrate $\mathrm{Pb}$ concentrations and the 
plant species (Zhang et al. 1998; Deng et al. 2004). There is evidence that some emergent wetland plants such as cattail, common reed (Ye et al. 2001), yellow flag (Iris pseudacorus L.) (Han et al. 2008), and the aquatic macrophyte Najas indica (Willd.) Cham. (Singh et al. 2010) have a greater ability to tolerate $\mathrm{Pb}$ and to accumulate it to some degree in their tissues. However, there is considerable variation between species in their responses to $\mathrm{Pb}$ (Deng et al. 2006). Lead-tolerant plants tend to be root accumulators showing restricted $\mathrm{Pb}$ translocation from root to shoot (Baker and Walker 1990; Shu et al. 2012). Previous studies have suggested that some wetland plant species accumulate very low $\mathrm{Pb}$ concentrations in their shoots even when grown in highly $\mathrm{Pb}$ contaminated substrates (Ye et al. 1997a, b, 2001; Deng et al. 2004, 2006) and employing an 'excluder' strategy (sensu Baker 1981). Other species, however, accumulate higher $\mathrm{Pb}$ concentrations in their shoot tissues without any visible toxicity symptoms. These observations suggest that some innate mechanisms of metal detoxification (e.g., antioxidant enzyme activities) may exist in at least some wetland plant species (Fediuc and Erdei 2002; Adhikari et al. 2010; Singh et al. 2010).

Lead is a non-essential element and at high concentrations can lead to alterations in the morphology and physiology of plants thought to be caused by reactive oxygen species (ROS) stress from hydroxyl $\left(\mathrm{OH}^{-}\right)$and superoxide radicals $\left(\mathrm{O}^{2-}\right)$ and hydrogen peroxide $\left(\mathrm{H}_{2} \mathrm{O}_{2}\right)$ which cause oxidative damage (Guo et al. 2004). For the protection against such damage to plant cells, increased activity of oxygen radical detoxifying enzymes, such as superoxide dismutase (SOD), catalase (CAT), and peroxidase (POD), may be induced in order to resist the oxidative stress caused by potentially toxic metal concentrations (Chaoui et al. 1997). SOD is a metalloenzyme that catalyzes the disproportionation of $\mathrm{O}^{2-}$ radicals to $\mathrm{H}_{2} \mathrm{O}_{2}$ and $\mathrm{O}_{2}$, and plays an important role in protecting cells against the toxic effects of superoxide radicals produced in different cellular compartments (Del Rio et al. 2002). POD catalyzes $\mathrm{H}_{2} \mathrm{O}_{2}$-dependent substrate oxidation, and POD activity is also considered a useful biomarker for sublethal metal toxicity (Podazza et al. 2012). CAT is one of the most important enzymes for the regulation of intracellular $\mathrm{H}_{2} \mathrm{O}_{2}$ levels affected by SOD catalyzed reactions (Blokhina et al. 2003). Recently, studies have indicated that these antioxidant enzymes may play an important role in the defensive mechanism of wetland plants against $\mathrm{Pb}$ and other heavy metals. This has been suggested for T. latifolia (Fediuc and Erdei 2002), P. australis (Ederli et al. 2004), Lemna minor L. (Hou et al. 2007), I. pseudacorus (Zhou et al. 2010), and Juncus effusus L. (Najeeb et al. 2011). However, the existence of any specific relationships between $\mathrm{Pb}$ tolerance and antioxidant enzymes across a wider range of wetland plants remains unclear.

The aims of the current study were (1) to compare the $\mathrm{Pb}$ tolerance, uptake, and accumulation in a wide range of wetland plants and (2) to determine the effects of $\mathrm{Pb}$ on antioxidant enzymes in these wetland plants. $\mathrm{As} \mathrm{Pb}$ is one of the commonest heavy metals in industrial wastewater and mine processing wastes such as tailings lagoons (Ye et al. 2004), the results from this screening study should provide useful information for the selection of appropriate wetland plant species in constructed wetlands designed for the treatment of industrial run-off waters and in the phytoremediation of slurried mine tailings contaminated with $\mathrm{Pb}$.

\section{Materials and methods}

Plant materials and $\mathrm{Pb}$ treatments

The 18 emergent-rooted wetland plants have been selected as they are (1) fast growing, (2) widely distributed, and (3) possess low nutrient requirement. The plant materials were collected from non-contaminated sites in Guangdong Province (Yang et al. 2014). Tillers of Acorus tatarinowii Schott, Alternanthera philoxeroides (Mart.) Griseb., Ceratopteris thalictroides (L.) Brongn., Cyperus alternifolius Rottb., Hydrocotyle vulgaris L., Panicum repens L., Rotala rotundifolia Buch.-Ham. ex Roxb., Veronica serpyllifolia L., and Zantedeschia aethiopica Spreng. were grown by vegetative propagation; the other nine species [Alocasia cucullata (Lour.) Schott, Echinodorus amazonicus Rataj, Echinodorus osiris var. rubra, Eleocharis geniculata (L.) Romer \& Schult., Fimbristylis monostachya (L.) Hassk., Jussiaea linifolia Vahl., Paspalum scrobiculatum L., Philydrum lanuginosum Banks et Sol. ex Gaertner, and Scirpus triqueter L.] were germinated from seed. Because of the differences in growth rates between these, individuals of the same species with similar shoot heights and root lengths were selected for a pot trial. Plant cultivation was conducted in a glasshouse in a randomized block design. The glasshouse was illuminated with cool-white fluorescent tubes, supplying a photon flux density of $300 \mu \mathrm{mol} \mathrm{m}{ }^{-2} \mathrm{~S}^{-1}$, a relative humidity of $85 \%$, and a light/dark cycle of $14 \mathrm{~h}$ day/10 $\mathrm{h}$ night. The day/night temperature regime was between 28 and $22{ }^{\circ} \mathrm{C}$.

The soil used in the pot trial was collected from a 'clean' paddy field $(0-20 \mathrm{~cm})$ at South China Agricultural University campus, located in Guangzhou City, Guangdong Province, PR China. It was spiked with $\mathrm{Pb}\left(900\right.$ and $1800 \mathrm{mg} \mathrm{kg}^{-1}$ supplied as $\left.\mathrm{Pb}\left(\mathrm{NO}_{3}\right)_{2}\right)$, then mixed thoroughly and allowed to equilibrate for 2 months. These two levels of $\mathrm{Pb}$ treatment were selected on the basis of results of our pilot experiments and other previous studies (Adhikari et al. 2010). Unamended soil served as a control. During the equilibration, the soil water was maintained at $70 \%$ of 
maximum water holding capacity by weight. After 2 months, the bulk soil was air-dried and passed through a $2-\mathrm{mm}$ sieve, and then $1 \mathrm{~kg}$ of air-dried soil was used in each pot. Physicochemical properties of the soil used for the experiment were $\mathrm{pH} 5.2$ (2.5:1 distilled water: soil, $v / w)$, organic matter content $17.54 \mathrm{~g} \mathrm{~kg}^{-1}$ $\left(\mathrm{K}_{2} \mathrm{CrO}_{7}-\mathrm{H}_{2} \mathrm{SO}_{4}\right.$ ), total $\mathrm{N} 0.836 \mathrm{~g} \mathrm{~kg}^{-1}$ (semi-quantitative titration), Olsen-P $28.74 \mathrm{mg} \mathrm{kg}{ }^{-1}\left(0.5 \mathrm{M} \mathrm{NaHCO}_{3}\right)$, available $\mathrm{K} 63.95 \mathrm{mg} \mathrm{kg}^{-1}$ (1.0 $\mathrm{M} \mathrm{NH}_{4} \mathrm{OAc}$ ), and total $\mathrm{Pb} 36 \mathrm{mg} \mathrm{kg}^{-1}$. To imitate wetland conditions, soils in the experimental units were maintained at $100 \%$ waterholding capacity for 2 weeks.

The initial heights of the 18 plant species used in the pot trial ranged from 15 to $20 \mathrm{~cm}$. For each species, two seedlings or tillers were transplanted into each pot and were grown under the same glasshouse conditions. There were three treatments employed in the pot trial (control, $900 \mathrm{mg} \mathrm{Pb} \mathrm{kg}^{-1}$ and $1800 \mathrm{mg} \mathrm{Pb} \mathrm{kg}{ }^{-1}$ ) with four replicates for each treatment/plant species. The pots were arranged in a fully randomized design on the glasshouse bench and their positions rotated regularly to ensure uniform growth conditions. After 40 days, $P$. lanuginosum in the $1800 \mathrm{mg} \mathrm{Pb} \mathrm{kg}{ }^{-1}$ treatments withered and died. At 120 days, plant height was measured for all other species and four leaves of each were removed, wrapped around with aluminium foil, and stored in liquid nitrogen for subsequent total soluble protein and antioxidant enzyme analysis. Plants were then carefully removed from the soil, separated into roots and shoots, thoroughly rinsed with deionized water, and then oven-dried at $70{ }^{\circ} \mathrm{C}$ to constant weight and used for the determination of biomass and $\mathrm{Pb}$ concentrations in root and shoot tissues.

Determination of total soluble proteins and antioxidant enzymes activities

Fresh leaf samples $(0.5 \mathrm{~g})$ were ground with liquid nitrogen and homogenized in $5 \mathrm{~mL}$ of $50 \mathrm{mmol}$ sodium phosphate buffer ( $\mathrm{pH}$ 7.0), including $0.5 \mathrm{mmol}$ EDTA and $0.15 \mathrm{~mol}$ $\mathrm{NaCl}$. The homogenate was centrifuged at $12,000 \mathrm{~g}$ for 10 min at $4{ }^{\circ} \mathrm{C}$, and the supernatant was used for protein determination and enzyme assays. Total soluble protein content was determined by the method of Bradford (1976) using BSA as a standard.

Superoxide dismutase (SOD) activity assay was based on the inhibition of the photochemical reduction of nitroblue tetrazolium (NBT) (Giannopolitis and Ries 1977). One unit of SOD activity was defined as the amount of protein inhibiting $50 \%$ of the initial reduction of NBT under illumination, expressed as $\mathrm{U} \mathrm{mg}^{-1}$ protein. Catalase (CAT) activity was assayed by the consumption of $\mathrm{H}_{2} \mathrm{O}_{2}$ conversion by changes in absorbance at $240 \mathrm{~nm}$ (Aebi 1984) and was expressed as $\mathrm{U} \mathrm{mg}^{-1}$ protein $\mathrm{min}^{-1}$. POD activity was determined after $\mathrm{H}_{2} \mathrm{O}_{2}$-induced guaiacol oxidation by absorbance change at $470 \mathrm{~nm}$ (Chance and Maehly 1955), again expressed as $\mathrm{U} \mathrm{mg}^{-1}$ protein $\mathrm{min}^{-1}$.

Analysis of $\mathrm{Pb}$ concentrations in plant tissues

Oven-dried root and shoot samples were homogenized using a Retsch grinder (Type: $2 \mathrm{~mm}$, Retsch Company, Germany) and then digested in $\mathrm{HNO}_{3}$ (Alexander et al. 2006). Sub-samples of plant tissue $(0.5 \mathrm{~g})$ were weighed into $200 \mathrm{~mL}$ block digestion tubes, concentrated nitric acid $(10 \mathrm{~mL})$ added and allowed to stand overnight. They were then heated for $3 \mathrm{~h}$ at $60{ }^{\circ} \mathrm{C}$, followed by $6 \mathrm{~h}$ at $110{ }^{\circ} \mathrm{C}$. After cooling, the digests were passed through pre-washed Whatman 540 filter papers (Whatman \& Co., UK). The digestion tubes were rinsed four times, passing through the filter each time, and the combined filtrates made up to $50 \mathrm{~mL}$ volume using ultrapure water. Lead concentrations in the digests were determined by inductivelycoupled plasma optical emission spectrometry (ICP-OES, Optima 2100, Perkin Elmer, USA). Blank and bush leaf material (BGW-07603) (China Standard Materials Research Center, Beijing, PR China) was used for quality control. The $\mathrm{Pb}$ recovery rates were $90 \pm 10 \%$.

\section{Statistical analysis}

Lead tolerance was quantified by a tolerance index (TI) calculated from a comparison between the growth of each plant in treatments with and without $\mathrm{Pb}$ additions (Wilkins 1978).

Tolerance index $(\%)=\frac{\text { dry weight in soil with } \mathrm{Pb}}{\text { dry weight in soil without } \mathrm{Pb}} \times 100$

Data on plant performance were tested for their normality and variance prior to a one-way analysis of variance (ANOVA). No data transformation was required. If the differences between plant species for each $\mathrm{Pb}$ treatment or between $\mathrm{Pb}$ treatments for each plant species were significant at the $5 \%$ level, the least significant difference (LSD) was calculated as a post hoc test. All statistical analyses were performed using the SPSS 11.0 statistical package.

\section{Results}

Effects of $\mathrm{Pb}$ on plant growth and tolerance index

The height and biomass dry weight of most species tested in the $\mathrm{Pb}$ treatments were significantly lower than those in the control. Tolerance indices for the 18 plant species varied from 29 to $82 \%$ in the $900 \mathrm{mg} \mathrm{Pb} \mathrm{kg}^{-1}$ and from 1 to $80 \%$ in the $1800 \mathrm{mg} \mathrm{Pb} \mathrm{kg}^{-1}$ treatments (Table 1). 
Table 1 Height (cm), biomass (g DW plant) and tolerance indices (TI, \% of control) of 18 species of wetland plants grown in soils at different $\mathrm{Pb}$ concentrations: $\mathrm{CK}$ (control, without $\mathrm{Pb}$ ), 900 and $1800 \mathrm{mg} \mathrm{Pb} \mathrm{kg}^{-1}$ (as $\mathrm{Pb}\left(\mathrm{NO}_{3}\right)_{2}$ ) treatments for 4 months (mean \pm S.E., $n=4$ )

\begin{tabular}{|c|c|c|c|c|c|c|c|c|c|c|}
\hline \multirow[t]{2}{*}{ Species } & \multicolumn{3}{|c|}{ Height (cm) } & \multirow[t]{2}{*}{$\mathrm{LSD}_{0.05}$} & \multicolumn{3}{|c|}{ Biomass (shoot + root) (g plant) } & \multirow[t]{2}{*}{$\operatorname{LSD}_{0.05}$} & \multicolumn{2}{|c|}{$\mathrm{Pb} \mathrm{TI}(\%)$} \\
\hline & CK & $\mathrm{Pb} 900$ & $\mathrm{~Pb} 1800$ & & CK & $\mathrm{Pb} 900$ & $\mathrm{~Pb} 1800$ & & $\mathrm{~Pb} 900$ & $\mathrm{~Pb} 1800$ \\
\hline A. tatarinowii & $25 \pm 0.5 \mathrm{a}$ & $26 \pm 1.1 \mathrm{a}$ & $20 \pm 1.3 b$ & 2.99 & $2.85 \pm 0.19 \mathrm{a}$ & $2.34 \pm 0.13 b$ & $2.29 \pm 0.09 \mathrm{~b}$ & 0.46 & 82 & 80 \\
\hline A. cucullata & $22 \pm 0.6 \mathrm{a}$ & $16 \pm 0.9 b$ & $13 \pm 0.7 \mathrm{c}$ & 2.28 & $3.61 \pm 0.09 \mathrm{a}$ & $2.83 \pm 0.13 b$ & $0.82 \pm 0.06 \mathrm{c}$ & 0.32 & 78 & 23 \\
\hline A. philoxeroides & $45 \pm 1.6 \mathrm{a}$ & $40 \pm 0.6 b$ & $26 \pm 1.1 \mathrm{c}$ & 3.52 & $1.22 \pm 0.08 \mathrm{a}$ & $0.81 \pm 0.03 b$ & $0.66 \pm 0.02 \mathrm{~b}$ & 0.16 & 66 & 54 \\
\hline C. thalictroides & $38 \pm 1.6 \mathrm{a}$ & $36 \pm 1.1 \mathrm{a}$ & $29 \pm 0.7 b$ & 3.64 & $1.78 \pm 0.04 \mathrm{a}$ & $1.09 \pm 0.13 b$ & $0.57 \pm 0.04 \mathrm{c}$ & 0.26 & 61 & 32 \\
\hline C.alternifolius & $42 \pm 0.9 \mathrm{a}$ & $38 \pm 0.7 b$ & $34 \pm 1.5 \mathrm{c}$ & 3.28 & $3.40 \pm 0.24 \mathrm{a}$ & $1.67 \pm 0.04 \mathrm{~b}$ & $1.20 \pm 0.03 c$ & 0.45 & 49 & 35 \\
\hline E. amazonicus & $16 \pm 0.9 \mathrm{a}$ & $10 \pm 0.7 b$ & $5 \pm 0.7 \mathrm{c}$ & 2.22 & $2.54 \pm 0.20 \mathrm{a}$ & $1.36 \pm 0.14 b$ & $0.29 \pm 0.04 c$ & 0.46 & 53 & 12 \\
\hline E. osiris & $12 \pm 0.4 \mathrm{a}$ & $8 \pm 0.5 b$ & $7 \pm 0.9 \mathrm{~b}$ & 2.16 & $0.93 \pm 0.07 \mathrm{a}$ & $0.40 \pm 0.02 b$ & $0.28 \pm 0.05 b$ & 0.17 & 43 & 30 \\
\hline E. geniculata & $29 \pm 1.1 \mathrm{a}$ & $21 \pm 1.2 b$ & $12 \pm 0.7 \mathrm{c}$ & 3.03 & $0.57 \pm 0.05 \mathrm{a}$ & $0.24 \pm 0.01 \mathrm{~b}$ & $0.18 \pm 0.01 \mathrm{~b}$ & 0.10 & 42 & 31 \\
\hline F. monostachya & $37 \pm 2.3 \mathrm{a}$ & $23 \pm 1.2 b$ & $19 \pm 0.9 b$ & 4.74 & $1.11 \pm 0.05 \mathrm{a}$ & $0.73 \pm 0.07 \mathrm{~b}$ & $0.51 \pm 0.08 \mathrm{~b}$ & 0.23 & 66 & 46 \\
\hline H. vulgaris & $17 \pm 0.2 \mathrm{a}$ & $13 \pm 0.7 b$ & $5 \pm 0.9 \mathrm{c}$ & 2.04 & $3.97 \pm 0.47 \mathrm{a}$ & $2.24 \pm 0.07 \mathrm{~b}$ & $0.53 \pm 0.07 \mathrm{c}$ & 0.89 & 57 & 14 \\
\hline J. linifolia & $47 \pm 2.1 \mathrm{a}$ & $31 \pm 2.2 b$ & $19 \pm 2.1 \mathrm{c}$ & 6.34 & $2.81 \pm 0.17 \mathrm{a}$ & $1.53 \pm 0.23 b$ & $0.27 \pm 0.03 \mathrm{c}$ & 0.45 & 55 & 1 \\
\hline P. repens & $63 \pm 1.3 \mathrm{a}$ & $58 \pm 2.3 \mathrm{a}$ & $46 \pm 2 b$ & 5.72 & $2.73 \pm 0.26 \mathrm{a}$ & $2.22 \pm 0.1 \mathrm{a}$ & $0.53 \pm 0.05 b$ & 0.53 & 81 & 19 \\
\hline P. scrobiculatum & $76 \pm 2.6 \mathrm{a}$ & $62 \pm 2.3 b$ & $45 \pm 1.1 \mathrm{c}$ & 6.40 & $0.67 \pm 0.04 \mathrm{a}$ & $0.47 \pm 0.02 \mathrm{~b}$ & $0.40 \pm 0.02 \mathrm{~b}$ & 0.10 & 70 & 59 \\
\hline P. lanuginosum & $50 \pm 2.9 \mathrm{a}$ & $28 \pm 1.9 b$ & - & 7.73 & $1.80 \pm 0.09 \mathrm{a}$ & $0.78 \pm 0.07 \mathrm{~b}$ & - & 0.28 & 43 & - \\
\hline R. rotundifolia & $28 \pm 2.3 \mathrm{a}$ & $10 \pm 0.7 b$ & $5 \pm 0.2 \mathrm{c}$ & 4.16 & $2.83 \pm 0.07 \mathrm{a}$ & $1.17 \pm 0.03 \mathrm{~b}$ & $0.12 \pm 0.01 \mathrm{c}$ & 0.15 & 41 & 5 \\
\hline S. triqueter & $63 \pm 2 \mathrm{a}$ & $39 \pm 3.3 b$ & $22 \pm 1.6 \mathrm{c}$ & 7.29 & $0.80 \pm 0.12 \mathrm{a}$ & $0.52 \pm 0.06 \mathrm{~b}$ & $0.25 \pm 0.04 \mathrm{c}$ & 0.14 & 64 & 31 \\
\hline V. serpyllifolia & $11 \pm 0.5 \mathrm{a}$ & $8 \pm 0.7 b$ & $6 \pm 0.4 \mathrm{c}$ & 1.40 & $2.16 \pm 0.27 \mathrm{a}$ & $0.62 \pm 0.10 \mathrm{~b}$ & $0.41 \pm 0.02 \mathrm{~b}$ & 0.53 & 29 & 9 \\
\hline Z. aethiopica & $50 \pm 2.7 \mathrm{a}$ & $46 \pm 1.2 \mathrm{a}$ & $34 \pm 2.8 b$ & 6.99 & $6.50 \pm 0.11 \mathrm{a}$ & $5.33 \pm 0.18 b$ & $4.02 \pm 0.20 \mathrm{c}$ & 0.54 & 82 & 62 \\
\hline
\end{tabular}

Different letters within the same row and the same index (height and biomass) indicate significant difference between the three treatments (CK, $\mathrm{Pb} 900$, and $\mathrm{Pb} 1800$ ) at the level of $P<0.05$. LSD value at $5 \%$ is indicated by $\operatorname{LSD}_{0.05}$ (the same below)

$\mathrm{Pb}$ concentrations in plant tissues

Lead concentrations in shoots of the 18 wetland plants grown in the control, 900 and $1800 \mathrm{mg} \mathrm{Pb} \mathrm{kg}{ }^{-1}$ treatments ranged from 4 to 36,13 to 749,49 to $18,650 \mathrm{mg} \mathrm{kg}^{-1}$, respectively. The ranges in roots were 18 to 65,1112 to 4891,2477 to $17,620 \mathrm{mg} \mathrm{kg}^{-1}$ (Table 2). The concentrations of $\mathrm{Pb}$ in root tissues increased significantly in the $\mathrm{Pb}$ treatments $(P<0.05)$.

Effects of $\mathrm{Pb}$ on protein contents and antioxidant enzyme activities

The protein contents and CAT activities in leaves of the plants were significantly reduced in the $\mathrm{Pb}$ treatments (Table 3). The degrees of reduction (in terms of $\%$ of the control) of protein and CAT activities were significantly different $(P<0.01)$ between the species tested, ranging from 3.2 to $69.3 \%$ and 1.9 to $18.4 \%$ in the $900 \mathrm{mg} \mathrm{Pb} \mathrm{kg}^{-1}$ treatment, respectively. The equivalent ranges in the $1800 \mathrm{mg} \mathrm{Pb} \mathrm{kg}^{-1}$ treatments were 6.6 to $92.1 \%$ and 3.7 to $22.9 \%$. However, activities of SOD and $\mathrm{POD}$ in leaves significantly increased in the $\mathrm{Pb}$ treatments. The degrees of increase (in terms of $\%$ of the control) of SOD and POD activities were also significantly different $(P<0.01)$, ranging from 4.8 to $152 \%$ and 4.7 to $81.8 \%$ in the $900 \mathrm{mg}$
$\mathrm{Pb} \mathrm{kg}^{-1}$ treatment, and from 13.1 to $104 \%$ and 16.2 to $108 \%$ in the $1800 \mathrm{mg} \mathrm{Pb} \mathrm{kg}^{-1}$ treatment, respectively.

Correlations between $\mathrm{Pb}$ tolerance indices, concentrations of $\mathrm{Pb}$ in roots and shoots, protein contents, and antioxidant enzyme activities

Significant correlations were apparent between protein contents; activities of SOD, POD, and CAT in Pb-treated plants; and their indices of $\mathrm{Pb}$ tolerance in the $\mathrm{Pb}$ treatments (Fig. 1). Negative correlations were suggested between $\mathrm{Pb}$ tolerance indices and the $\mathrm{Pb}$ concentrations in roots and shoots in $\mathrm{Pb}$ treated plants in the $\mathrm{Pb}$ treatments (Fig. 2). Negative correlations were also found between protein contents and these $\mathrm{Pb}$ concentrations in the tissues of the 18 wetland species in the control and $\mathrm{Pb}$ treatments (Fig. 2).

\section{Discussion}

$\mathrm{Pb}$ tolerance and accumulation by the wetland plant species

Plant growth (biomass) is usually reduced when plants are challenged with high levels of Pb (Ye et al. 1997a, b; Deng 
Table 2 Lead concentration ( $\mathrm{mg} \mathrm{kg}^{-1}$ dry weight) in shoots and roots of 18 species of wetland plants grown in soils spiked without (control, CK) and with $\mathrm{Pb}\left(900\right.$ and $1800 \mathrm{mg} \mathrm{Pb} \mathrm{kg}^{-1}$ as $\left.\mathrm{Pb}\left(\mathrm{NO}_{3}\right)_{2}\right)$ for 4 months (mean \pm S.E., $n=3$ )

\begin{tabular}{|c|c|c|c|c|c|c|c|c|}
\hline \multirow[t]{2}{*}{ Species } & \multicolumn{3}{|l|}{ Shoot } & \multirow[t]{2}{*}{$\mathrm{LSD}_{0.05}$} & \multicolumn{3}{|l|}{ Root } & \multirow[t]{2}{*}{$\mathrm{LSD}_{0.05}$} \\
\hline & CK & $\mathrm{Pb} 900$ & $\mathrm{~Pb} 1800$ & & CK & $\mathrm{Pb} 900$ & $\mathrm{~Pb} 1800$ & \\
\hline A. tatarinowii & $6 \pm 0.6 b$ & $13 \pm 1 b$ & $107 \pm 10 \mathrm{a}$ & 20.9 & $31 \pm 1.5 \mathrm{c}$ & $1315 \pm 18 b$ & $8222 \pm 140 \mathrm{a}$ & 281 \\
\hline A. cucullata & $11 \pm 1.2 \mathrm{c}$ & $43 \pm 4.8 b$ & $114 \pm 7 \mathrm{a}$ & 16.8 & $36 \pm 2.2 \mathrm{c}$ & $2092 \pm 145 b$ & $6979 \pm 119 a$ & 375 \\
\hline A. philoxeroides & $22 \pm 1.2 b$ & $43 \pm 1.2 b$ & $295 \pm 16 \mathrm{a}$ & 31.6 & $37 \pm 4.7 \mathrm{c}$ & $2084 \pm 115 b$ & $7448 \pm 56 a$ & 256 \\
\hline C. thalictroides & $18 \pm 1.8 \mathrm{c}$ & $89 \pm 5.5 b$ & $312 \pm 17 \mathrm{a}$ & 36.0 & $65 \pm 10.5 \mathrm{c}$ & $3950 \pm 2.2 b$ & $8470 \pm 1207 a$ & 2445 \\
\hline C.alternifolius & $3 \pm 0.9 \mathrm{c}$ & $73 \pm 2.3 b$ & $146 \pm 6 \mathrm{a}$ & 12.6 & $34 \pm 4.8 \mathrm{c}$ & $1607 \pm 168 b$ & $3373 \pm 178 \mathrm{a}$ & 489 \\
\hline E. amazonicus & $10 \pm 0.6 b$ & $84 \pm 4.4 b$ & $2329 \pm 156 a$ & 312 & $22 \pm 0.9 \mathrm{c}$ & $3164 \pm 115 b$ & $6261 \pm 412 \mathrm{a}$ & 854 \\
\hline E. osiris & $14 \pm 1.2 \mathrm{c}$ & $738 \pm 34 b$ & $18650 \pm 596 a$ & 1193 & $25 \pm 2.9 \mathrm{c}$ & $3148 \pm 395 b$ & $10,612 \pm 445 \mathrm{a}$ & 1188 \\
\hline E. geniculata & $36 \pm 5 \mathrm{c}$ & $437 \pm 32 b$ & $1905 \pm 135 \mathrm{a}$ & 277 & $45 \pm 2.2 \mathrm{c}$ & $2769 \pm 170 b$ & $8236 \pm 249 a$ & 602 \\
\hline F. monostachya & $9 \pm 0.9 b$ & $46 \pm 6.1 b$ & $177 \pm 23 \mathrm{a}$ & 47.0 & $60 \pm 3.5 \mathrm{c}$ & $1715 \pm 40 \mathrm{~b}$ & $4892 \pm 121 \mathrm{a}$ & 254 \\
\hline H. vulgaris & $6 \pm 0.9 c$ & $116 \pm 7.2 b$ & $535 \pm 27 \mathrm{a}$ & 56.8 & $22 \pm 1.2 \mathrm{c}$ & $1112 \pm 86 b$ & $3732 \pm 281 \mathrm{a}$ & 588 \\
\hline J. linifolia & $7 \pm 0.9 \mathrm{~b}$ & $234 \pm 32 \mathrm{a}$ & $186 \pm 19 a$ & 74.2 & $18 \pm 4.3 \mathrm{c}$ & $3962 \pm 545 b$ & $17,620 \pm 687 \mathrm{a}$ & 1752 \\
\hline P. repens & $4 \pm 0.3 \mathrm{c}$ & $106 \pm 4 b$ & $308 \pm 42 \mathrm{a}$ & 84.5 & $37 \pm 1.2 \mathrm{c}$ & $1994 \pm 155 b$ & $5104 \pm 87 \mathrm{a}$ & 355 \\
\hline P. scrobiculatum & $33 \pm 0.9 \mathrm{c}$ & $98 \pm 6 b$ & $220 \pm 4 a$ & 14.0 & $94 \pm 4.9 \mathrm{c}$ & $1461 \pm 161 b$ & $2477 \pm 132 \mathrm{a}$ & 416 \\
\hline P. lanuginosum & $8 \pm 1.2 b$ & $384 \pm 80 \mathrm{a}$ & - & 223 & $29 \pm 1.2 b$ & $6374 \pm 224 a$ & - & 621 \\
\hline R. rotundifolia & $27 \pm 3.4 \mathrm{c}$ & $749 \pm 29 b$ & $3581 \pm 312 \mathrm{a}$ & 627 & $59 \pm 2.9 \mathrm{c}$ & $4891 \pm 339 b$ & $13582 \pm 683 a$ & 1524 \\
\hline S. triqueter & $6 \pm 0.9 b$ & $78 \pm 8 b$ & $2130 \pm 103 a$ & 207 & $61 \pm 1.9 c$ & $4590 \pm 296 b$ & $4891 \pm 319 a$ & 869 \\
\hline V. serpyllifolia & $12 \pm 1.3 b$ & $216 \pm 56 b$ & $5286 \pm 431 \mathrm{a}$ & 868 & $21 \pm 2 c$ & $2141 \pm 107 b$ & $8245 \pm 216 a$ & 482 \\
\hline Z. aethiopica & $5 \pm 0.6 \mathrm{c}$ & $25 \pm 2 b$ & $49 \pm 4 \mathrm{a}$ & 8.42 & $62 \pm 5.5 c$ & $1884 \pm 69 b$ & $5330 \pm 214 a$ & 450 \\
\hline
\end{tabular}

Note: Different letters within the same row and the same index (shoot and root) indicate significant difference between the three treatments $(\mathrm{CK}$, $\mathrm{Pb} 900$, and $\mathrm{Pb} 1800)$ at the level of $P<0.05$ level

et al. 2006). The present study clearly showed that dry weights of most of the wetland species tested were reduced in $\mathrm{Pb}$ treatments compared to the control, but the degrees of reduction differed significantly between plant species suggesting different intrinsic $\mathrm{Pb}$ tolerance between them. In addition, our data suggested that there are negative correlations between $\mathrm{Pb}$ concentrations in roots and shoots in $\mathrm{Pb}$-treated plants and their $\mathrm{Pb}$ tolerance indices (Fig. 2). This indicates that the plants with higher $\mathrm{Pb}$ tolerance indices tend to accumulate lower concentrations of $\mathrm{Pb}$ in their roots and shoots when grown under $\mathrm{Pb}$ treatment stress.

Concentrations of $\mathrm{Pb}$ in shoots and roots also showed significant differences between the species in the same $\mathrm{Pb}$ treatment (Table 2), also demonstrating different abilities in $\mathrm{Pb}$ transport and accumulation. Concentrations of $\mathrm{Pb}$ in roots were higher than those in shoot tissues $(P<0.05)$. This is due to the operation of an exclusion mechanism and so the concentrations of heavy metals in the shoots of plants are maintained at a constant low level when grown in metalcontaminated soils of variable $\mathrm{Pb}$ status (Baker 1981). The notably low $\mathrm{Pb}$ concentrations in shoots of $A$. tatarinowii and Z. aethiopica (49-107 mg kg-1) also explains why plants grown in the $1800 \mathrm{mg} \mathrm{Pb} \mathrm{kg}^{-1}$ treatment did not show any visible $\mathrm{Pb}$ toxicity symptoms. However, even $P$. scrobiculatum, having the highest accumulation of $\mathrm{Pb}$ in shoots (up to $220 \mathrm{mg} \mathrm{Pb} \mathrm{kg}^{-1}$ ) still did not show any severe symptoms of $\mathrm{Pb}$ toxicity. These findings indicate that internal mechanisms of $\mathrm{Pb}$ detoxification may also exist in some wetland plants, such as $P$. scrobiculatum, in addition to the exclusion mechanism. Baker (1981) also suggested that internal (genetically-determined) tolerance mechanisms can exist in plants when grown in heavy metal-contaminated soils.

Effects of $\mathrm{Pb}$ on protein contents and antioxidant enzyme activities

Metal stress can act at different cellular sites to inhibit enzymes having functional sulfhydryl groups. In the present study, both $\mathrm{Pb}$ treatments induced the decline in soluble protein contents and CAT activities in most of the species tested (Table 3). However, the species with higher $\mathrm{Pb}$ tolerance indices tended to have higher protein contents, SOD, and POD activities (Fig. 1), suggesting that there were indeed internal $\mathrm{Pb}$ detoxification mechanisms in the wetland species tested. Increased protein content is possibly due to the induction of stress proteins even under low metal exposure (Srivastava et al. 2005). However, in the present study, the reduction of protein contents in most species in the 900 and $1800 \mathrm{mg} \mathrm{Pb} \mathrm{kg}{ }^{-1}$ treatments may be due to 


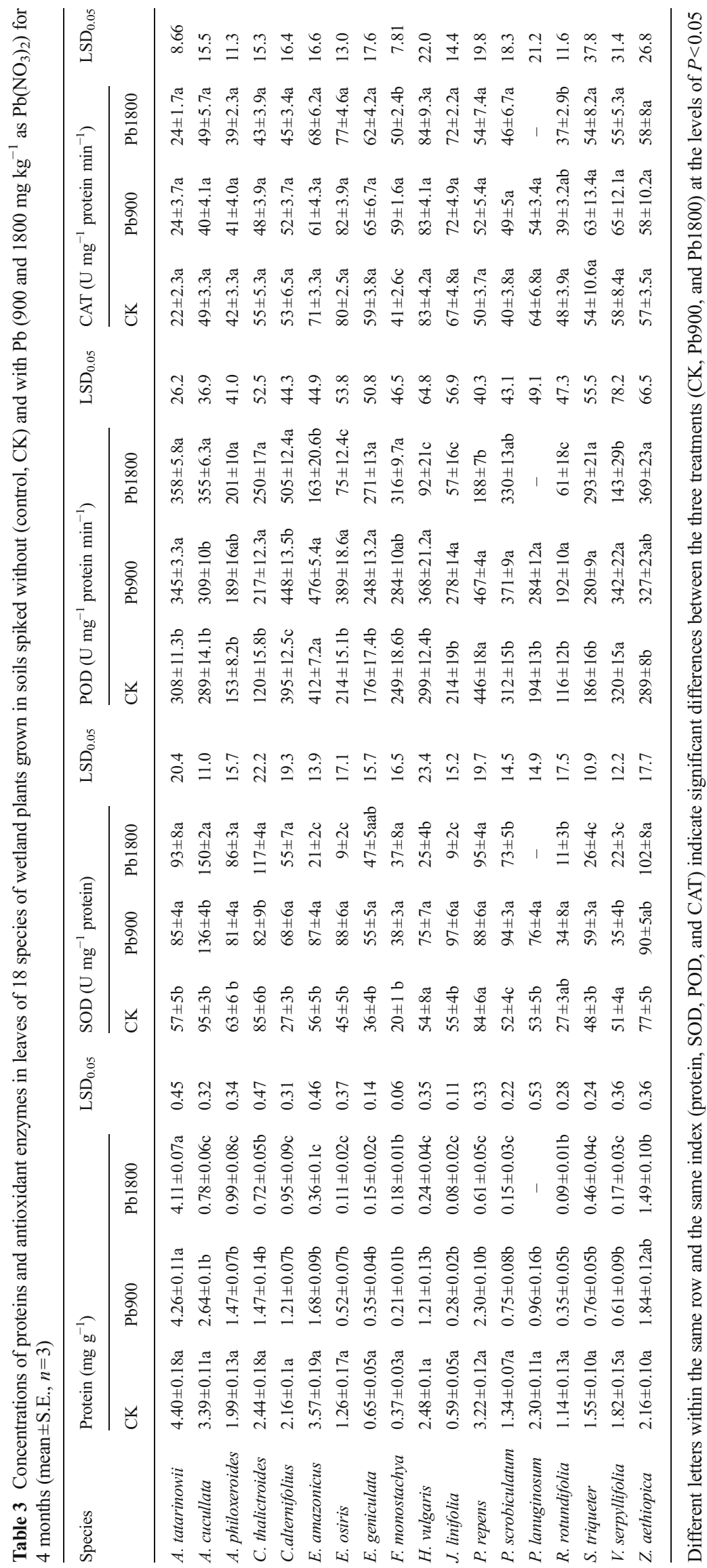



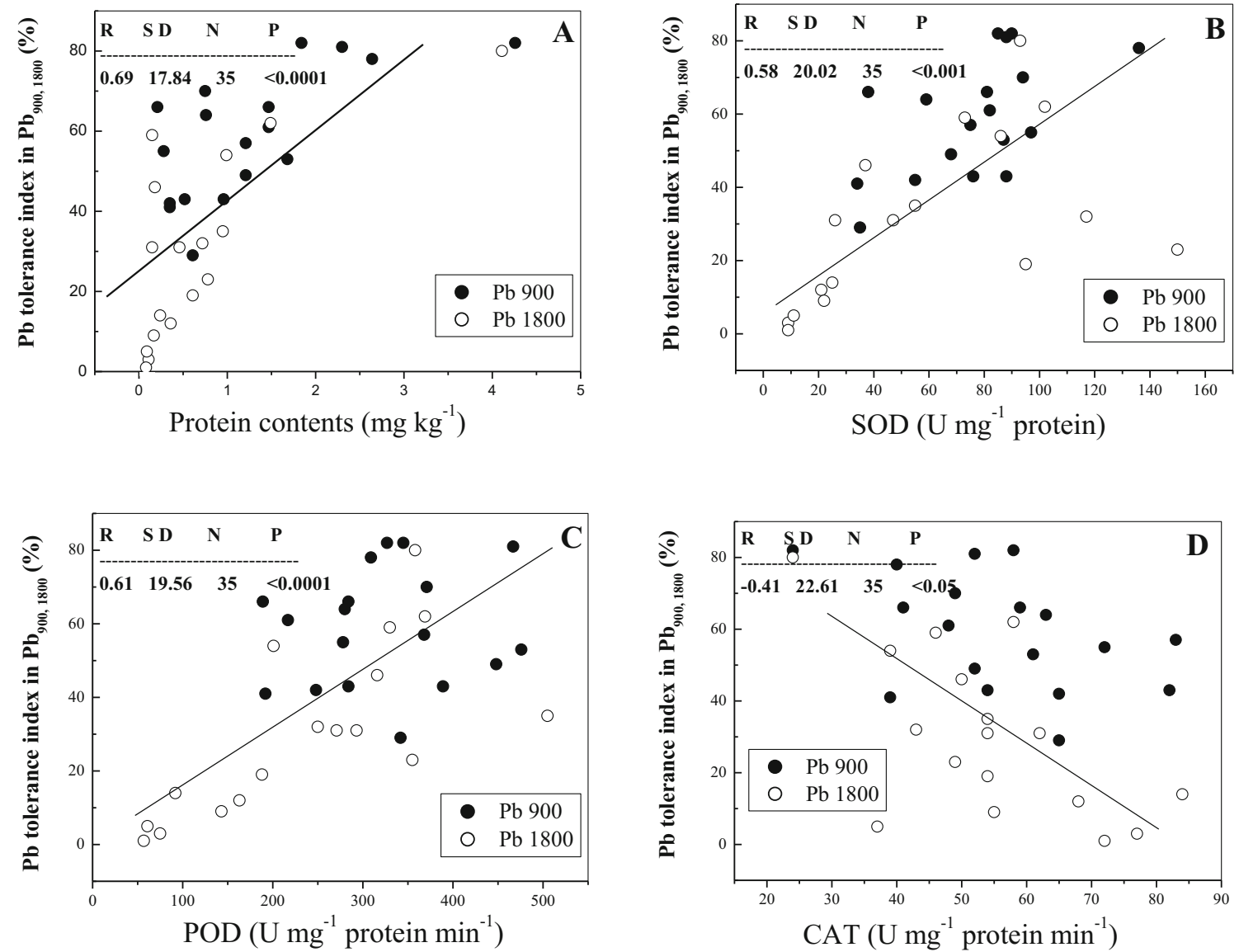

Fig. 1 Correlations between $\mathrm{Pb}$ tolerance index and protein contents (a), Superoxide dismutase (SOD) (b), peroxidase (POD) (c), and catalase CAT (d) activities of the 18 species of wetland plants grown in 900 and $1800 \mathrm{mg} \mathrm{kg}^{-1} \mathrm{~Pb}$ treatments in pot culture

degradation by proteases as a result of high metal exposure (Romero-Puertas et al. 2002; Hou et al. 2007). Our results also showed significant negative correlations between $\mathrm{Pb}$ concentrations of roots and shoots in the $\mathrm{Pb}$-treated plants and their protein contents (Fig. 2). Similar studies by other workers have shown that the protein content of plants is decreased by $\mathrm{Pb}$ accumulation (Mohan and Hosetti 1997; Singh et al. 2010), suggesting that the wetland species here with lower concentrations of $\mathrm{Pb}$ in their biomass tended to have higher protein contents and decreased degradation by proteases under $\mathrm{Pb}$ exposure.

Increased SOD activity with increased level of $\mathrm{Pb}$ in soils in most of the 18 species may be attributed to the increased production of active oxygen species, which the results in an increase in expression of the gene encoding SOD (Bowler et al. 1992; Fatima and Ahmad 2005), suggesting that this increase provides increased protection against oxidative damage (Singh et al. 2010).

Previous studies with metal-tolerant plant species have reported that POD activity is found to be sufficiently high to enable the plants to protect themselves against oxidative stress
(Uraguchi et al. 2006; Kovacik and Klejdus 2008; Adhikari et al. 2010). In the present study, our results showed that those species with higher $\mathrm{Pb}$ tolerance were able to maintain higher levels of POD activity under higher Pb stress. POD also participates in lignin biosynthesis (Podazza et al. 2012), an important tolerance mechanism protecting the protoplast from toxic effects of heavy metals (Wojcik et al. 2005; Adhikari et al. 2010). It suggests that the wetland species with higher POD activity may be more efficient in avoiding damage from $\mathrm{Pb}$.

For most species tested, a decline in CAT activity with increasing levels of $\mathrm{Pb}$ in soils may be attributed to enzyme inhibition, because $\mathrm{Pb}$ binds to the thiol group of this enzyme (Ouzounidou et al. 1997) or causes disruption of protein synthesis as well as direct damage to proteins (Srivastava and Dubey 2011). Some experimental data reported by other workers also suggest that the variations in POD and CAT activities under oxidative stress are contradictory: an increase, a decrease, or no change (Shaw 1995; Boscolo et al. 2003; Singh et al. 2010). This can perhaps be attributed to differences between species, plant tissues studied, or the duration and concentrations of metal exposure (Radic et al. 2010). Our data presented here, together with the previous reports, 

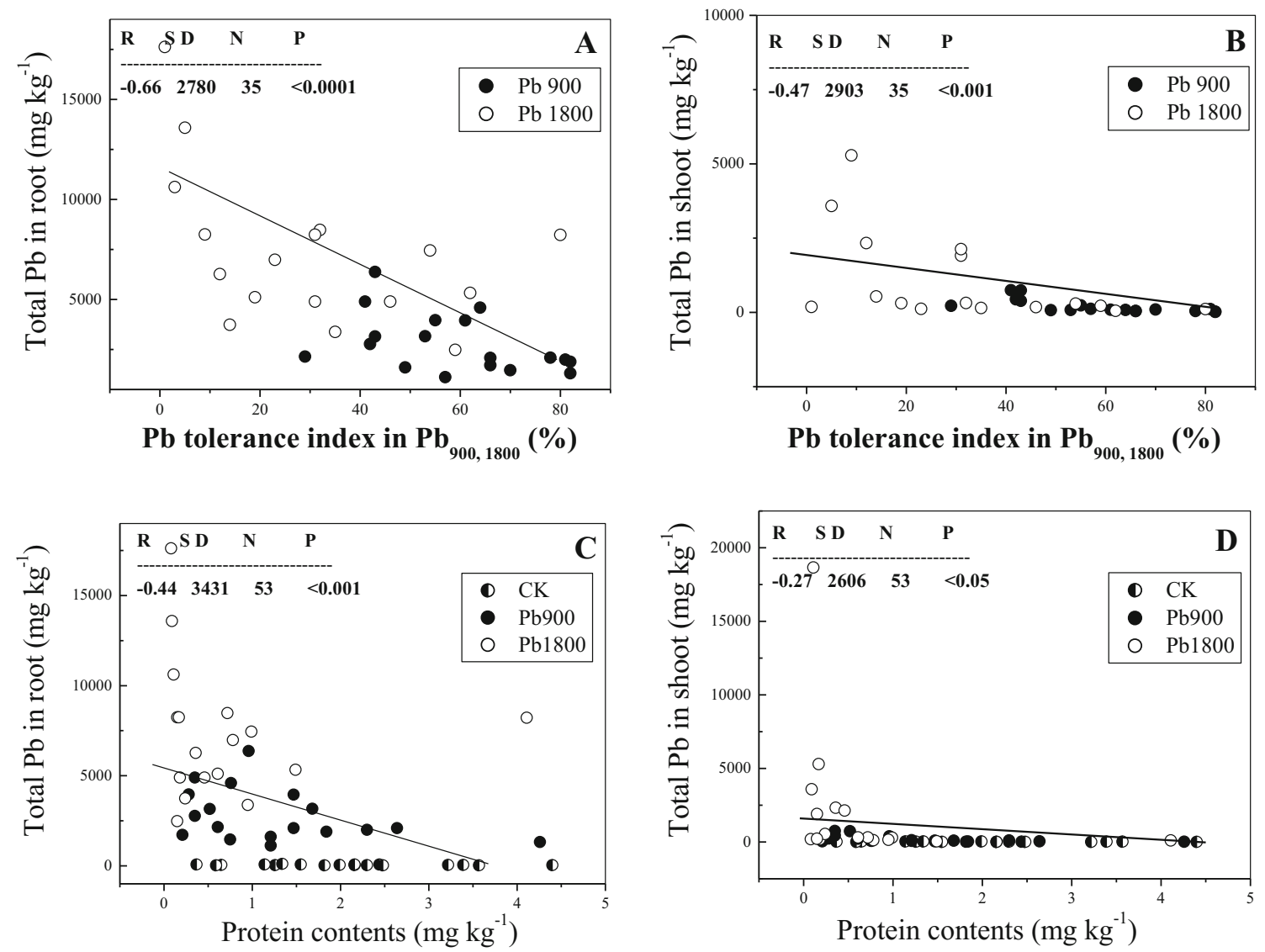

Fig. 2 Correlations between total concentrations of $\mathrm{Pb}$ in roots $(\mathbf{a}, \mathbf{c})$ or shoots $(\mathbf{b}, \mathbf{d})$ and $\mathrm{Pb}$ tolerance index or protein contents of the 18 species of wetland plants grown in the control, 900 and $1800 \mathrm{mg} \mathrm{kg}^{-1} \mathrm{~Pb}$ treatments in pot culture

suggest that antioxidant enzymes may have important roles in internal $\mathrm{Pb}$ detoxification in wetland plants.

In summary, our results showed that there are significant differences in $\mathrm{Pb}$ tolerance and accumulation between the wetland plants. The plants with higher $\mathrm{Pb}$ tolerances tended to have lower $\mathrm{Pb}$ accumulation but higher protein contents, $\mathrm{SOD}$, and POD activities in their shoots when exposed to $\mathrm{Pb}$. The results suggest that an 'excluder' strategy and an internal mechanism of $\mathrm{Pb}$ detoxification by antioxidant enzyme activities are both widely employed and play important roles in $\mathrm{Pb}$ tolerance in wetland plants. The existence of clear differences in the responses to $\mathrm{Pb}$ of the 18 species tested in this study will be helpful in the selection of species for use in constructed wetlands to limit the environmental impact of $\mathrm{Pb}$ contamination in effluents and drainage waters.

Acknowledgments This research was financially supported by the National Natural Science Foundation of China (No. 30570345, 41201312), Specialized Research Fund for the Doctoral Program of Higher Education of China (20558097), and Key Laboratory of Biodiversity Dynamics and Conservation of Guangdong Higher Education Institutes, Sun Yat-sen University. We thank Prof AJM Baker (Universities of Melbourne and Queensland, Australia, and Sheffield, UK) for his help in the early stages of the preparation on this paper.

\section{References}

Adhikari T, Kumar A, Singh MV, Rao AS (2010) Phytoaccumulation of lead by selected wetland plant species. Commun Soil Sci Pl Anal 41: 2623-2632

Aebi H (1984) Catalase in vitro. Methods Enzymol 105:121-126

Alexander PD, Alloway BJ, Dourado AM (2006) Genotypic variations in the accumulation of $\mathrm{Cd}, \mathrm{Cu}, \mathrm{Pb}$, and $\mathrm{Zn}$ exhibited by six common grown vegetables. Environ Pollut 144:736-745

Baker AJM (1981) Accumulators and excluders-strategies in the response of plants to heavy metals. J Plant Nutr 3:643-654

Baker AJM, Walker PL (1990) Ecophysiology of metal uptake by tolerant plants. In: Shaw AJ (ed) Heavy metal tolerance in plants: Evolutionary aspects. CRC Press, Boca Raton, pp 155-177

Blokhina O, Virolainen E, Fagerstedt KV (2003) Antioxidants, oxidative damage and oxygen deprivation stress: a review. Ann Bot 91:179-194

Boscolo PRS, Menossi M, Jorge RA (2003) Aluminum-induced oxidative stress in maize. Phytochemistry 62:181-189

Bowler C, Vanmontagu M, Inze D (1992) Superoxide-dismutase and stress tolerance. Annu Rev Plant Physiol Plant Mol Biol 43:83-116

Bradford MM (1976) A rapid and sensitive method for the quantitation of microgram quantities of protein utilizing the principle of protein-dye binding. Anal Biochem 72:248

Chance B, Maehly A (1955) Assay of catalases and peroxidases. Methods Enzymol 2:764-775

Chaoui A, Mazhoudi S, Ghorbal MH, El Ferjani E (1997) Cadmium and zinc induction of lipid peroxidation and effects on antioxidant enzyme activities in bean (Phaseolus vulgaris L.). Plant Sci 127: $139-147$ 
Del Rio LA, Corpas FJ, Sandalio LM, Palma JM, Gomez M, Barroso JB (2002) Reactive oxygen species, antioxidant systems and nitric oxide in peroxisomes. J Exp Bot 53:1255-1272

Deng H, Ye ZH, Wong MH (2004) Accumulation of lead, zinc, copper and cadmium by 12 wetland plant species thriving in metalcontaminated sites in China. Environ Pollut 132:29-40

Deng H, Ye ZH, Wong MH (2006) Lead and zinc accumulation and tolerance in populations of six wetland plants. Environ Pollut 141:69-80

Ederli L, Reale L, Ferranti F, Pasqualini S (2004) Responses induced by high concentration of cadmium in Phragmites australis roots. Physiol Plantarum 121:66-74

Fatima RA, Ahmad M (2005) Certain antioxidant enzymes of Allium cepa as biomarkers for the detection of toxic heavy metals in wastewater. Sci Total Environ 346:256-273

Fediuc E, Erdei L (2002) Physiological and biochemical aspects of cadmium toxicity and protective mechanisms induced in Phragmites australis and Typha latifolia. J Plant Physiol 159:265-271

Giannopolitis CN, Ries SK (1977) Superoxide dismutases I. Occurrence in higher plants. Plant Physiol 59:309-314

Guo TR, Zhang GP, Zhou MX, Wu FB, Chen JX (2004) Effects of aluminum and cadmium toxicity on growth and antioxidant enzyme activities of two barley genotypes with different $\mathrm{Al}$ resistance. Plant Soil 258:241-248

Han YL, Huang SZ, Gu JG, Qiu S, Chen JM (2008) Tolerance and accumulation of lead by species of Iris L. Ecotoxicology 17:853859

Hou WH, Chen X, Song GL, Wang QH, Chang CC (2007) Effects of copper and cadmium on heavy metal polluted water body restoration by duckweed (Lemna minor). Plant Physiol Biochem 45:62-69

Kovacik J, Klejdus B (2008) Dynamics of phenolic acids and lignin accumulation in metal-treated Matricaria chamomilla roots. Plant Cell Rep 27:605-615

Li PJ, Wang X, Wang MX, Allinson G, Li XJ, Xiong XZ (2009) Risk assessment of heavy metals in soil previously irrigated with industrial wastewater in Shenyang, China. J Hazard Mater 161:516-521

Li B, Wang X, Qi XL, Huang L, Ye ZH (2012) Identification of rice cultivars with low brown rice mixed cadmium and lead contents and their interactions with the micronutrients iron, zinc, nickel and manganese. J Environ Sci 24(10):1790-1798

Liu JG, Ma XM, Wang MX, Sun XW (2013) Genotypic differences among rice cultivars in lead accumulation and translocation and the relation with grain $\mathrm{Pb}$ levels. Ecotox Eniviron Safe 90:35-40

Mohan BS, Hosetti BB (1997) Potential phytotoxicity of leaf and cadmium to Lemna minor grown in sewage stabilization ponds. Environ Pollut 98:233-238

Najeeb U, Jilani G, Ali S, Sarwar M, Xu L, Zhou WJ (2011) Insights into cadmium induced physiological and ultra-structural disorders in Juncus effusus L. and its remediation through exogenous citric acid. J Hazard Mater 186:565-574

Ouzounidou G, Moustakas M, Eleftheriou EP (1997) Physiological and ultrastructural effects of cadmium on wheat (Triticum aestivum L.) leaves. Arch Environ Con Tox 32:154-160

Podazza G, Arias M, Prado FE (2012) Cadmium accumulation and strategies to avoid its toxicity in roots of the citrus rootstock Citrumelo. J Hazard Mater 215:83-89

Radic S, Babic M, Skobic D, Roje V, Pevalek-Kozlina B (2010) Ecotoxicological effects of aluminum and zinc on growth and antioxidants in Lemna minor L. Ecotox Environ Safe 73:336-342

Romero-Puertas MC, Palma JM, Del Rio A, Sandalio LM (2002) Cadmium causes the oxidative modification of proteins in pea plants. Plant Cell Environ 25:677-686

Sharma RK, Agrawal M, Marshall F (2007) Heavy metal contamination of soil and vegetables in suburban areas of Varanasi, India. Ecotox Environ Safe 66:258-266
Shaw BP (1995) Effects of mercury and cadmium on the activities of antioxidative enzymes in the seedling of Phaseolus aureus. Biol Plantarum 37:587-596

Sheoran AS, Sheoran V (2006) Heavy metal removal mechanism of acid mine drainage in wetlands: a critical review. Miner Eng 19:105-116

Shu X, Yin LY, Zhang QF, Wang WB (2012) Effect of Pb toxicity on leaf growth, antioxidant enzyme activities, and photosynthesis in cuttings and seedlings of Jatropha curcas L. Environ Sci Pollut Res 19: 893-902

Singh KP, Mohon D, Sinha S, Dalwani R (2004) Impact assessment of treated/untreated wastewater toxicants discharge by sewage treatment plants on health, agricultural, and environmental quality in wastewater disposal area. Chemos 55:227-255

Singh R, Tripathi RD, Dwivedi S, Kumar A, Trivedi PK, Chakrabarty (2010) Lead bioaccumulation potential of an aquatic macrophyte Najas indica are related to antioxidant system. Bioresource Technol 101:3025-3032

Srivastava S, Dubey RS (2011) Manganese-excess induces oxidative stress, lowers the pool of antioxidants and elevates activities of key antioxidative enzymes in rice seedlings. Plant Growth Regul 64:1-16

Srivastava M, Ma LQ, Singh N, Singh S (2005) Antioxidant responses of hyper-accumulator and sensitive fern species to arsenic. J Exp Bot 56:1335-1342

Uraguchi S, Watanabe I, Yoshitomi A, Kiyono M, Kuno K (2006) Characteristics of cadmium accumulation and tolerance in novel Cd-accumulating crops, Avena strigosa and Crotalaria juncea. J Exp Bot 57:2955-2965

Vymazal J (2011) Plant used in constructed wetlands with horizontal subsurface flow: a review. Hydrobiologia 674:133-156

Wilkins DA (1978) The measurement of tolerance to edaphic factors by means of root growth. New Phytol 80:623-633

Wojcik M, Vangronsveld J, D’Haen J, Tukiendorf A (2005) Cadmium tolerance in Thlaspi caerulescens - II. Localization of cadmium in Thlaspi caerulescens. Environ Exp Bot 53:163-171

Wright DJ, Otte ML (1999) Wetland plant effects on the biogeochemistry of metals beyond the rhizosphere. Biol Environ: Proceeding of the Royal Irish Academy 99:3-10

Yang JX, Tam NFY and Ye ZH (2014). Root porosity, radial oxygen loss and iron plaque of wetland plants in relation to zinc tolerance and accumulation. Plant Soil 374:815-828

Ye ZH, Baker AJM, Wong MH, Willis AJ (1997a) Zinc, lead and cadmium tolerance, uptake and accumulation by Typha latifolia. New Phytol 136:469-480

Ye ZH, Baker AJM, Wong MH, Willis AJ (1997b) Zinc, lead and cadmium tolerance, uptake and accumulation by the common reed, Phragmites australis (Cav.) Trin. ex Steudel. Ann Bot 80:363-370

Ye ZH, Whiting SN, Lin ZQ, Lytle CM, Qian JH, Terry N (2001) Removal and distribution of iron, manganese, cobalt and nickel within a Pennsylvania constructed wetland treating coal combustion by-product leachate. J Environ Qual 30:1464-1473

Ye ZH, Wong MH, Lan CY (2004) Use of a wetland system for treating $\mathrm{Pb} / \mathrm{Zn}$ mine effluent: a case study in southern China from 1984 to 2002. In: Wong MH (ed) Wetland ecosystems in Asia: Function and management. Elsevier, Amsterdam, pp 413-434

Zhang ZW, Takao W, Shinichiro S, Higashikawa K, Ikeda M (1998) Pb and cadmium contents in cereals and pulses in north-eastern China. Sci Tot Environ 220:137-145

Zhou YQ, Huang SZ, Yu SL, Gu JG, Zhao JZ, Han YL, Fu JJ (2010) The physiological response and sub-cellular location of lead and cadmium in Iris pseudacorus. Ecotoxicology 19:69-76

Zhuang P, McBride MB, Xia HP, Li NY, Li ZA (2009) Health risk from heavy metals via consumption of food crops in the vicinity of Dabaoshan mine, South China. Sci Total Environ 407:1551-1561 